\title{
Food Hygiene Principles On Processing Practices Course At Vocational High School Culinary Major
}

\author{
Teti Setiawati, Eddy Sutadji, Djoko Kustono \\ Department of Industrial Technology \\ Department of Mechanical Engineering Education \\ Universitas Negeri Malang \\ Malang, Indonesia \\ teti.setiawati.ft@um.ac.id
}

\author{
Luthfiyah Nurlaela \\ Departement of Home Economic \\ Universitas Negeri Surabaya \\ Surabaya, Indonesia \\ luthfiyahn@yahoo.com
}

\begin{abstract}
Food safety namely the release of food from contamination, is the main thing and important to note. In order to produce food that is safe to eat, one of them is to pay attention to the principles of food hygiene during food processing practices. This study aims to examine the implementation of the principles of food hygiene on the learning of processing practices carried out in the In Vocational High School of Culinary Skill Program. The principles of food hygiene studied include: (1) personal hygiene; (2) selection of foodstuffs; (3) Food storage; (4) Processing; (5) Storage of processed food; (6) Transportation; and (7) Service. The population in this study is the students of class XI SMK Culinary Expertise Program In Malang Raya. The sample size is 204 students, the sample is taken using proportional random sampling. The result of descriptive analysis showed that the students' behavior in implementing the principles of food hygiene $89.2 \%$ included in the category very well with the average of 3.89 . The results of the analysis of each variable include: (1) Personal hygiene $84.3 \%$ included in very good category with average 3,84 ; (2); Selection of $83.8 \%$ material included in very good category with average 3,84 ; (3) Storage of 68.1\% material included in very good category with mean 3.58; (4) Processing $69.6 \%$ included in very good category with average 3,67 ; (5) Storage of processed food $64.2 \%$ included in very good category with average 3,64 ; (6) Transportation is categorized as either 3.52 ; (7) The service of $76.0 \%$ included in very good category with a mean of $3, .76$. Theresults of this study can be used as an entry for schools, as it is important to improve food safety practices for students in schools.
\end{abstract}

Keywords-food hygiene principles, processing practices, culinary students vocational school

\section{INTRODUCTION}

Healthy foods are foods that can meet nutritional and hygienic requirements. Hygienic means free from chemical, biological, and physical contamination so safe to be consumed. For that to produce food that is safe for consumption, food processing Should pay attention to the principles of food hygiene. Successful implementation of the procedures based on the $\mathrm{HACCP}$ principles will require the full cooperation and commitment [7]

Principles of hygiene that are important and should be implemented in food processing practices are: (1) Personal hygiene. (2) Selection of foodstuffs. (3) Food storage. (4) Processing. (5) Storage of processed food. (6) Transportation of processed food. (7) Serving food

\section{METHODS}

\section{A. Research Design}

This type of research is explanatory research which is expost facto. The research population is students of Vocational High School (VHS) of Culinary Skill Program in Malang Raya Indonesia as many as 414 students. The sample size is 204 students taken by proprtional random sampling from 10 VHS Catering Skill Program in Malang Raya Indonesia (Malang District, Batu Municipality, and Malang Municipality). Data collection is done in the semester of 3 of academic year 2016/2017. Data collection is done through observation. The purpose of obtaining a description of student hygiene behavior during food processing practices. The observed behavior includes behavior that demonstrates the application of the principles of food hygiene from personal hygiene, selection of foodstuffs, food storage, processing, storage of processed food, transportation of processed food, until serving food.

\section{B. Instrument}

Instrument created and developed by researchers to measure student behavior, is a check list.

\section{Data Analysis}

Analyzes to the collected data used SPSS 20.0 software. To know the aspects of student hygiene behavior, and dominant aspects. 


\section{RESULTS}

Based on the results of the collection through observation shows the following results.

\section{A. Implementation of Food Hygiene Principles on Food Processing Practices}

The results of the analysis about the implementation of the food hygiene principles on the processing practice, can be seen through Table 1.

TABLE 1 THE IMPLEMENTATION OF FOOD HYGIENE PRINCIPLES ON PROCESSING PRACTICE COURSE

\begin{tabular}{|l|c|c|}
\hline \multicolumn{1}{|c|}{ Category } & F & \% \\
\hline Very good & 182 & 89,2 \\
\hline Good & 22 & 10,8 \\
\hline Total & 204 & 100,0 \\
\hline
\end{tabular}

Table 1 shows that in general $(89.2 \%)$, respondents have applied the principles of food hygiene to the practice of processing very well. Furthermore, the following data reveal about the application of each aspect of the principles of food hygiene from personal hygiene, selection of foodstuffs, food storage, processing, storage of processed food, transportation of processed food, until serving food.

\section{B. The Implementation of The Food Hygiene Principles Aspects of on The Processing Practice}

The results of the analysis about the implementation of the food hygiene principles aspect on the processing practice, can be seen through Table 2

TABLE 2 THE IMPLEMENTATION OF THE FOOD HYGIENE PRINCIPLES ASPECTS ON PROCESSING PRACTICE

\begin{tabular}{|c|c|c|c|c|c|c|}
\hline \multirow{2}{*}{\multicolumn{2}{|c|}{ Aspect }} & \multicolumn{4}{|c|}{ Respondents Answer } & \multirow{4}{*}{$\begin{array}{c}\text { Average } \\
3.77\end{array}$} \\
\hline & & \multirow{3}{*}{$\begin{array}{c}\begin{array}{c}\text { Not } \\
\text { Good }\end{array} \\
0 \\
0.0 \\
\end{array}$} & \multirow{3}{*}{$\begin{array}{c}\text { Poorly } \\
2 \\
1.0\end{array}$} & \multirow{3}{*}{\begin{tabular}{c|} 
Good \\
43 \\
21.1 \\
\end{tabular}} & \multirow{3}{*}{$\begin{array}{c}\begin{array}{c}\text { Very } \\
\text { Good }\end{array} \\
159 \\
77.9 \\
\end{array}$} & \\
\hline & $\mathrm{F}$ & & & & & \\
\hline Y1.1 & $\%$ & & & & & \\
\hline \multirow{2}{*}{ Y1.2 } & $\mathrm{F}$ & 0 & 15 & 56 & 133 & \multirow{2}{*}{3.58} \\
\hline & $\%$ & 0.0 & 7.4 & 27.5 & 65.2 & \\
\hline \multirow{2}{*}{ Y1.3 } & $\mathrm{F}$ & 0 & 2 & 32 & 170 & \multirow{2}{*}{3.82} \\
\hline & $\%$ & 0.0 & 1.0 & 15.7 & 83.3 & \\
\hline \multirow{2}{*}{ Y1.4 } & $\mathrm{F}$ & 0 & 3 & 46 & 155 & \multirow{2}{*}{3.75} \\
\hline & $\%$ & 0.0 & 1.5 & 22.5 & 76.0 & \\
\hline \multirow{2}{*}{ Y1.5 } & $\mathrm{F}$ & 0 & 6 & 77 & 121 & \multirow{2}{*}{3.56} \\
\hline & $\%$ & 0.0 & 2.9 & 37.7 & 59.3 & \\
\hline \multirow{2}{*}{ Y1.6 } & $\mathrm{F}$ & 2 & 4 & 50 & 148 & \multirow{2}{*}{3.69} \\
\hline & $\%$ & 1.0 & 2.0 & 24.5 & 72.5 & \\
\hline \multirow{2}{*}{ Y1.7 } & $\mathrm{F}$ & 0 & 18 & 54 & 132 & \multirow{2}{*}{3.56} \\
\hline & $\%$ & 0.0 & 8.8 & 26.5 & 64.7 & \\
\hline \multirow{2}{*}{ Y2.1 } & $\mathrm{F}$ & 0 & 1 & 46 & 157 & \multirow{2}{*}{3.76} \\
\hline & & 0.0 & 0.5 & 22.5 & 77.0 & \\
\hline \multirow{2}{*}{ Y2.2 } & $\mathrm{F}$ & 14 & 5 & 50 & 135 & \multirow{2}{*}{3.50} \\
\hline & $\%$ & 6.9 & 2.5 & 24.5 & 66.2 & \\
\hline \multirow{2}{*}{ Y2.3 } & $\mathrm{F}$ & 0 & 3 & 39 & 162 & \multirow{2}{*}{3.78} \\
\hline & $\%$ & 0.0 & 1.5 & 19.1 & 79.4 & \\
\hline \multirow[b]{2}{*}{ Y2.4 } & $\mathrm{F}$ & 0 & 2 & 52 & 150 & \multirow{2}{*}{3.73} \\
\hline & $\%$ & 0.0 & 1.0 & 25.5 & 73.5 & \\
\hline
\end{tabular}

TABLE 2. CONT

\begin{tabular}{|c|c|c|c|c|c|c|}
\hline \multirow{2}{*}{\multicolumn{2}{|c|}{ Aspect }} & \multicolumn{4}{|c|}{ Respondents Answer } & \multirow{4}{*}{$\begin{array}{c}\text { Average } \\
3.73\end{array}$} \\
\hline & & \multirow{3}{*}{$\begin{array}{c}\begin{array}{c}\text { Not } \\
\text { Good }\end{array} \\
0 \\
0.0 \\
\end{array}$} & \multirow{3}{*}{$\begin{array}{c}\text { Poorly } \\
0 \\
0.0\end{array}$} & \multirow{3}{*}{$\begin{array}{c}\text { Good } \\
55 \\
27.0\end{array}$} & \multirow{3}{*}{$\begin{array}{c}\begin{array}{c}\text { Very } \\
\text { Good }\end{array} \\
149 \\
73.0\end{array}$} & \\
\hline \multirow{2}{*}{ Y2.5 } & $\mathrm{F}$ & & & & & \\
\hline & $\%$ & & & & & \\
\hline \multirow{2}{*}{ Y3.1 } & $\mathrm{F}$ & 1 & 6 & 102 & 95 & \multirow{2}{*}{3.43} \\
\hline & $\%$ & 0.5 & 2.9 & 50.0 & 46.6 & \\
\hline \multirow{2}{*}{ Y3.2 } & $\mathrm{F}$ & 0 & 17 & 74 & 113 & \multirow{2}{*}{3.47} \\
\hline & $\%$ & 0.0 & 8.3 & 36.3 & 55.4 & \\
\hline \multirow{2}{*}{ Y4.1 } & $\mathrm{F}$ & 0 & 8 & 99 & 96 & \multirow{2}{*}{3.43} \\
\hline & $\%$ & 0.0 & 3.9 & 48.8 & 47.3 & \\
\hline \multirow{2}{*}{ Y4.2 } & $\mathrm{F}$ & 0 & 7 & 104 & 93 & \multirow{2}{*}{3.42} \\
\hline & $\%$ & 0.0 & 3.4 & 51.0 & 45.6 & \\
\hline \multirow{2}{*}{ Y4.3 } & $\mathrm{F}$ & 0 & 22 & 89 & 93 & \multirow{2}{*}{3.35} \\
\hline & $\%$ & 0.0 & 10.8 & 43.6 & 45.6 & \\
\hline \multirow{2}{*}{ Y4.4 } & $\mathrm{F}$ & 0 & 16 & 81 & 107 & \multirow{2}{*}{3.45} \\
\hline & $\%$ & 0.0 & 7.8 & 39.7 & 52.5 & \\
\hline \multirow{2}{*}{ Y4.5 } & $\mathrm{F}$ & 0 & 22 & 88 & 94 & \multirow{2}{*}{3.35} \\
\hline & $\%$ & 0.0 & 10.8 & 43.1 & 46.1 & \\
\hline \multirow{2}{*}{ Y4.6 } & F & 0 & 18 & 104 & 81 & 23 \\
\hline & $\%$ & 0.0 & 8.9 & 51.2 & 39.9 & 3.31 \\
\hline & $F$ & 0 & 4 & 89 & 111 & $25 ?$ \\
\hline Y5.1 & & 0.0 & 2.0 & 43.6 & 54.4 & 3.52 \\
\hline & $\mathrm{F}$ & 0 & 10 & 53 & 141 & \\
\hline Y5.2 & $\%$ & 0.0 & 4.9 & 26.0 & 69.1 & 3.64 \\
\hline Y5 3 & $\mathrm{~F}$ & 0 & 6 & 94 & 104 & 348 \\
\hline 15.3 & $\%$ & 0.0 & 2.9 & 46.1 & 51.0 & 3.48 \\
\hline Y5 4 & $\mathrm{~F}$ & 0 & 8 & 105 & 90 & 340 \\
\hline 15.4 & $\%$ & 0.0 & 3.9 & 51.7 & 44.3 & 3.40 \\
\hline Y61 & $\mathrm{F}$ & 0 & 46 & 91 & 67 & 310 \\
\hline & $\%$ & 0.0 & 22.5 & 44.6 & 32.8 & 5.10 \\
\hline Y6? & $\mathrm{F}$ & 0 & 0 & 81 & 123 & \\
\hline Y0.2 & $\%$ & 0.0 & 0.0 & 39.7 & 60.3 & 3.00 \\
\hline Y7.1 & $\mathrm{F}$ & 0 & 12 & 120 & 72 & 329 \\
\hline 17.1 & $\%$ & 0.0 & 5.9 & 58.8 & 35.3 & 3.29 \\
\hline Y7 2 & $\mathrm{~F}$ & 0 & 2 & 82 & 120 & 358 \\
\hline 17.2 & $\%$ & 0.0 & 1.0 & 40.2 & 58.8 & \\
\hline Y7 3 & $\mathrm{~F}$ & 0 & 3 & 60 & 141 & 368 \\
\hline Y 7.3 & $\%$ & 0.0 & 1.5 & 29.4 & 69.1 & 3.68 \\
\hline Y74 & $\mathrm{F}$ & 0 & 5 & 67 & 132 & 362 \\
\hline 11.4 & $\%$ & 0.0 & 2.5 & 32.8 & 64.7 & 3.02 \\
\hline Y7 5 & $\mathrm{~F}$ & 0 & 5 & 70 & 129 & 361 \\
\hline 11.0 & $\%$ & 0.0 & 2.5 & 34.3 & 63.2 & 5.01 \\
\hline Y76 & $\mathrm{F}$ & 0 & 5 & 85 & 114 & 353 \\
\hline 11.0 & $\%$ & 0.0 & 2.5 & 41.7 & 55.9 & 5.53 \\
\hline Y77 & $\mathrm{F}$ & 0 & 11 & 71 & 122 & 354 \\
\hline 1.18 & $\%$ & 0.0 & 5.4 & 34.8 & $\begin{array}{l}59.8 \\
\end{array}$ & 5.54 \\
\hline
\end{tabular}

Based on Table 2, it can be seen from the average that in applying the principle of personal hygiene (Y1), respondents generally apply or pay attention to aspects of personal hygiene (Y1.1) very well (3.77). It is also shown that as many as $77.9 \%$ of respondents almost always pay attention to body hygiene, $21.1 \%$ often, and only $1 \%$ sometimes. Then in applying the hand hygiene aspect (Y1.2), $65.2 \%$ of respondents applied hand hygiene and nails very well, and $27.5 \%$ of respondents applied good hand hygiene and nails. The average this item at 3:58 indicate most respondents apply hygiene very good hands and nails.

Furthermore in the aspect of hair hygiene (Y1.3), at most $83.3 \%$ of respondents apply very good hair hygiene, and $15.7 \%$ of respondents apply good hair hygiene. The average of 
this item of 3.82 shows that most respondents apply very good hair hygiene.

Next aspect of oral and dental hygiene (Y1.4), at most $76.0 \%$ of respondents applied very good oral and dental hygiene, and $22.5 \%$ of respondents applied good oral and dental hygiene. The average of this item of 3.75 shows that most respondents applied very good oral and dental hygiene.

Then the aspect of the completeness in the use of personal protective equipment (Y1.5), at most $59.3 \%$ of respondents apply the equipments of personal protective equipment used very well, and $37.7 \%$ used good. The average of this item of 3.56 indicates that most respondents apply a very good use of personal protective equipment.

Furthermore, the aspect of cleanliness in the use of personal protective equipment (Y1.6), at most $72.5 \%$ of respondents applied the cleanliness of personal protective equipment used very well, and $24.5 \%$ of respondents apply good personal protective equipment cleanliness. The average of this item of 3.69 shows that most respondents applied the cleanliness of personal protective equipment used very well.

The next aspect of tidiness in the use of personal protective equipment (Y1.7), at most $64.7 \%$ of respondents applied the neatness of personal protective equipment used very well, and $26.5 \%$ of respondents apply neatness of personal protective equipment. The average of this item of 3.56 indicates that most respondents apply the neatness of personal protective equipment used very well.

Furthermore, the aspect of the selection of foodstuffs (Y2), at most $77.0 \%$ of respondents apply the selection of foodstuffs with food recipes aspect (Y2.1) is very good, and $22.5 \%$ good. The average of this item of 3.76 shows most respondents in applying the selection of foodstuffs with food recipes aspect is very good.

Then the quality aspect/condition of foodstuff (Y2.2), at most $66.2 \%$ of respondents apply the aspect of the quality/condition of the foodstuff is very good, and $24.5 \%$ good. The average of this item of 3.50 indicates that most respondents in applying aspects of the quality/condition of the foodstuff are good.

The next aspect of selection based on the quantity of foodstuff (Y2.3), 79.4\% of respondents most often apply the selection based on the quantity of foodstuff are very good, and $19.1 \%$ is good. The average of this item of 3.78 shows that most respondents applied the selection based on the quantity of foodstuff are very good.

Furthermore, the aspect of foodstuff hygiene (Y2.4), at most $73.5 \%$ of respondents applied aspects of foodstuff hygiene is very good, and $25.5 \%$ good. The average of this item of 3.73 shows that most respondents applied the hygiene of foodstuff aspects are very well.

The next aspect of selection of natural additives (Y2.5), $73.0 \%$ of the respondents applied the selection of natural additives is very good, and $27.0 \%$ of respondents apply the selection of natural additives are good. The average of this item of 3.73 shows that most respondents applied the selection of natural additives very well.

Furthermore, the principle of storing foodstuffs (Y3), at most $50 . \%$ of respondents applying the suitability of storage temperature with foodstuff (Y3.1) good, and 46.6\% very good. The average of this item of 3.43 shows most respondents applying foodstuff storage based on the storage temperatures. are good. The next aspect of cleanliness of foodstuffs and storage devices (Y3.2), at most 55.4\% of respondents applied cleanliness of place and foodstuff storage equipment very well, and $36.3 \%$ good. The average of this item of 3.47 shows that most respondents applied cleanliness of the place and the foodstuff storage are good.

Furthermore, the principle of food processing (Y4), at most $48.8 \%$ of respondents apply the preparation of food processing (Y.4.1) good, and $47.3 \%$ very good. The average of this item of 3.43 shows that most respondents applied of food preparation preparations are good.

Then the aspect of cleanliness of the place of processing (Y.4.2), at most $51.0 \%$ of respondents apply cleanliness of the good processing place, and $45.6 \%$ very good. The average of this item of 3.42 shows that most of the respondents apply cleanliness of the processing place are good.

Furthermore, the hygiene aspects of processing equipment (Y4.3), at most $45.6 \%$ of respondents applied the cleanliness of food processing equipment is very good, and $43.6 \%$ good. The average of this item of 3.35 indicates that most respondents apply the food processing hygiene are good.

The following aspects of the suitability of processing techniques with the foodstuff (Y4.4), at most $52.5 \%$ of respondents apply the suitability of processing techniques with foodstuff are very good, and $39.7 \%$ good. The average of this item of 3.45 shows most respondents applying the suitability of the processing technique with the foodstuff are good.

Then the conformity aspect of the tool with the processing technique (Y4.5), at most $46.1 \%$ of respondents apply the suitability of the tool with processing techniques are very good, and $43.1 \%$ good. The average of this item of 3.35 shows most respondents applying the suitability of the tool with the processing technique is good.

The next aspect of processing equipment conformity with the amount of processed ingredient foods (Y4.6), at most $51.1 \%$ of respondents applying the suitability of processing equipment to the amount of processed ingredient food is good, and $39.9 \%$ is very good. The average of this item of 3.31 shows most respondents applying the suitability of processing equipment to the amount of processed ingredient food is good.

Furthermore, the principle of storage of processed foods (Y5), at most $54.4 \%$ of respondents applied aspects of container conditions (Y5.1) very good, and $43.6 \%$ good. The average of this item of 3.52 indicates that most respondents apply the conditions of the container very well.

Then the conformity aspect of storage containers with the type of dish (Y5.2), at most $69.1 \%$ of respondents apply the suitability of storage containers with the type of dish is very good, and $26.0 \%$ good. The average of this item of 3.64 shows that most respondents apply the suitability of the storage containers with the type of dish very well.

The next aspect of hygiene storage area (Y 5.3), the most common $51.0 \%$ of the respondents to apply hygiene storage area very well, and $46.1 \%$ good. On average this item 
amounted to 3.48 showed most respondents apply hygiene storage area is good.

The next aspect of how food storage that have been processed (Y 5.4), 51.7\% of respondents most widely applying aspects of how food storage that have been processed properly, and $44.3 \%$ very good. On average this item amounted to 3.40 shows that most respondents are implementing aspects of how food storage that has been processed is good.

Further the principle of the carriage (Y6), the most common $44.6 \%$ of the respondents to apply aspects equipment transport containers (Y 6.1) is good, and $32.8 \%$ very good. On average this item amounted to 3.10 shows the majority of the respondents to apply aspects equipment container transport is good.

Then the engineering aspect/how the carriage ( $Y$ 6.2), the most common $60.3 \%$ of the respondents to apply engineering/transportation way and $39.7 \%$ is good. The average of 3.60 items showed most respondents apply engineering/transport way is very good.

Further the principle of serving food that has been processed (Y7), 58.8\% of respondents most frequently apply the compliance aspects of the equipment for the type of food dish (Y 7.1) is good, and $35.3 \%$ very good. On average this item amounted to 3.29 showed most respondents implement aspects of the suitability of the equipment with this type of dish is good.

Then the aspect of conformity tool by number of dishes (Y 7.2), 58.8\% of respondents most frequently apply the suitability of equipment with a number of excellent dishes, and $40.2 \%$ of respondents either.

On average this item amounted to 3.58 showed most respondents implement compliance tool by number of dishes was very good.

The next aspect of equipmeent hygiene (Y 7.3), 69.1\% of respondents most frequently apply the suitability of tools with different types of dishes are excellent, and $29.4 \%$ good. On average this item amounted to 3.68 showed most respondents implement compliance tool with this type of dish is very good.

The next aspect of cleanliness of tables/place the dish (Y 7.4), the most common $64.7 \%$ of respondents implement aspects of table/place hygiene the dishes very well, and $32.8 \%$ good. On average this item amounted to 3.62 showed most respondents hygiene aspects of table/place the dish very well.

Then the aspects of hygiene of dishes (Y 7.5), 63.2\% of respondents most widely implemented aspects of the cleanliness of the dishes very well, and $34.3 \%$ good. On average this item amounted to 3.61 showed most respondents implement aspects of the cleanliness of the dishes very well.

The next aspect of cleanliness to garnish (Y 7.6), the most common $55.9 \%$ of respondents implement aspects of hygiene to garnish, and $41.7 \%$ good. On average this item amounted to 3.54 showed most respondents implement aspects of hygiene to garnish.
Next aspect of portion conformity (Y7.7) at most $64.7 \%$ of respondents apply the aspect of suitability of portion is very good, and $32.8 \%$ good. The average of this item of 3.62 shows most respondents applying portion compliance is excellent.

\section{DISCUSSION}

The quality of the food is well processed in terms of taste, aroma, appearance, nutrition, and safety, depends on the processing. Therefore, in practice or food processing processes need to implement the principles of food hygiene. In this study, the implementation of the principles of food hygiene in question is the ability of students as food processors or food handlers in implementing the principles of food hygiene during food processing practices. It is closely related to food hygiene issues, that is, all the conditions and actions necessary to ensure food safety at every stage of the food processing chain.

According to Susan, W. Arendt, Paola Paez, dan Catherine Strohbehn [10], the top priority of customer service is to ensure that the food served is safe for consumption, because otherwise the company risks losing its reputation, finances, even closing the company and deal with the law if it causes food poisoning or foodborne illness.

The steps that must be considered for the food produced safe for consumption, among others, ranging from personal hygiene food handlers themselves, selection of foodstuffs, storage of food, processing, storage of processed foods, and serving. personal hygiene, food selection, food storage, processing, food storage, and presentation.

Yoder, R.A. [11] research, suggest that improper food handling practices and lack of knowledge in food hygiene from food handlers are a factor in the transfer of food pathogens that cause disease outbreaks. Anuradha, and R.H.'s Dandekar [2] research, to the attitude and behavior of food handlers on foodborne diseases suggests that a good attitude towards the importance of hand washing, and the use of gloves for the use of gloves to prevent contamination affect the practice of food processing. This means the hygiene attitude of food handlers in terms of hand washing and using gloves, can form the behavior of higine food handlers.

Krunagar [5] revealed that when food handlers do not understand the dangers of hygiene, hygienic attitudes and behaviors at food processing are also low. In other words, if food handlers have adequate knowledge of the principles of food hygiene, then hygiene behavior in food processing will be better along with a positive attitude toward the knowledge it has.

Angelillo, I. F. [1]; Anuradha, and R.H. Dandekar, [2]; Bas, M., Ersun, A.S. [2]; George Amponsah Annor, [4]; Mohd Onn Rashdi Abd Patah [9]; In general, research on knowledge, attitudes and hygiene behavior towards traders, as well as students of Culinary Vocational Schools on the learning of food processing practices, is more aimed at personal hygiene, and how to wash hands.

The process of organizing food until ready to be served and eaten is usually taken through stages called the food chain. 
The food chain is a sequence of steps and operations in the production, processing, distribution, storage, and handling of a food and its ingredients, from primary production to consumption (SNI ISO 2000: 2009). Regulation of the Head of the National Agency of Drug and Food Control of the Republic of Indonesia No. HK.03.1.23.04.12.2206 Year 2012 states that to produce a quality product and safe, the production process must be controlled properly. Thus controlling the food processing process is important and must be considered because it is the core activity of the preparation of tools and materials until ready to eat food that requires a direct contact between food handlers with food to be processed.

Maskur in Maharani [6] suggests that the food service industry (catering) and household food products become the biggest cause of food poisoning. Poisoning occurs because of irregularities in the processing or production process. Food poisoning arises in several of aspects that allow the occurrence of errors in the selection of materials, the use of processing equipment, food storage and hygiene sanitation food processors. The phenomenon shows that the problem of food production has not been paid maximally attention in order to improve food safety and food production process in Indonesia.

Control of the food processing process should be considered because the processing is the core activity of the preparation of tools and materials until the food is ready to be consumed. Process of processing, there is direct contact or touch between food handlers with food to be processed. At the time of food processing, food handlers give treatment to the foodstuff either cut only, wash and peel that is very possible the occurrence of contamination resulting in food poisoning.

Manufacturers as the party that produces food as equipped with knowledge and skills about how to produce good food so that the food is safe to eat. Food producers are not limited to large-scale home industries, factories and industries, but to all those who produce and process of food.

\section{CONCLUSION}

This study found that the implementation of the principles of food hygiene by students at the time of food processing practices is in good category. The principle of food hygiene is the most prominent student controlled that is with regard to personal hygiene.

\section{ACKNOWLEDGMENT}

The research project was funded by self, because this research is the dissertation part. Therefore the contents are solely the responsibility of the authors

\section{REFERENCES}

[1] Angelillo, I. F., Viggiani, N. M. A., Rizzo, L., \& Bianco, A. Food Handlers and Food Borne Diseases: Knowledge, Attitudes, and Reported Behavior in Italy. Journal of Food Protection, 63 (3), $381^{-} 385$. From https://doi.org/10.4315/0362-028X-63.3.381. 2000

[2] Anuradha, and Dandekar, R.H. Knowledge, Attitude and Practice among Food Handlers on Food Borne Diseases: A Hospital Based Study in Tertiary Care Hospital. International Journal of Biomedical and Advance Research. 05 (04) $2229^{-}$3809. From www.ssjournals.com. OI:10.7439/ijbar. 2014.

[3] Bas, M., Ersun, A.S., Kivan, G. The Evaluation of Food Hygiene Knowledge, Attitude and Practice of Food Handler in Food Businesses in Turkey. Food Control Journal, 17: 317-322. 2006.

[4] George, A.A. dan Ekua, A.B. Evaluation of Food Hygiene Knowledge Attitudes and Practices of Food Handlers in Food Businesses in Accra, Ghana. Journal of Food and Nutrition Sciences, 2, 830-836. 2011.

[5] Krunagar, I. International Risk Assessment Leading to Development of Food Safety Standards. Journal Procedia Social and Behaviour Science, 6. From https://doi.org/10.1016/j.profoo.2016.02.00. 2016.

[6] Maharani, C.A. Penyusunan Rencana Hazard Analysis Critical Control Points (HACCP) di PT. Pangan Rahmat Buana, Sentul-Bogor, (Online),

(http://repository.ipb.ac.id/bitstream/handle/123456789/12032/F08cam. pdf?sequence=2). 2008.

[7] M. Jevšnik, V. Hlebec, and P. Raspor, "Food safety knowledge and practices among food handlers in Slovenia," Food Control, vol. 19, no. 12, pp. 1107-1118, 2008.

[8] Mohd Onn Rashdi Abd Patah, Zuraini Mat Issa, Khamis Mohammad Nor. Food Safety Attitude of Culinary Arts Based Students in Public and Private Higher Learning Institutions (IPT). International Education Studies. www.ccsenet.org/journal.html. 2009.

[9] Susan, W. Arendt, Paola Paez, dan Catherine Strohbehn. Food Safety Practices and Managers' Perceptions: A Qualitative Study in Hospitality. International Journal of Contemporary Hospitality Management 24 [2013):124, doi:10.1108/09596111311290255.2013.

[10] Yoder, R. A. Knowledge, Attitudes, and Practices Survey: Baseline Evaluation In Aragatsotn, Armavir, and Ararat Marzes. Armenia The United States Agency for International Development (USAID): The Primary Health Care Reform (PHCR) Project. 2008. 